DOI: 10.17805/zpu.2020.2.6

\title{
Роль самотворчества в становлении индивидуальности в Античности: духовные упражнения «научиться общению с Другим» и «научиться умирать»
}

\author{
A. А. ГОРЕЛОВ \\ ИНСТИТУТ ФИЛОСОФИИ РАН, \\ Т. А. ГОРЕЛОВА \\ МОСКОВСКИЙ ГУМАНИТАРНЫЙ УНИВЕРСИТЕТ
}

Работа является завершением цикла работ авторов по проблеме самотворчества (СТ) в Античности. Прослеживаются позиции различных философских школ - Платона, Аристотеля, киников, эпикурейцев и стоиков - в ракурсе четырех типов духовных упражнений, предложенных П. Адо, - «научиться жить», «научиться вести диалог», «научиться чтению», «научиться умирать» (упражнению «научиться жить» посвящена наша статья в предыдущем номере журнала).

Практическая направленность античной философии вполне рационально толкала человека к самоизменению, она создала методологию CT - самоконтроль как способность не растрачивать себя в обыденной жизни и созерцание как способность к расширению сознания. Главной составляющей обоих уровней является устремленность. Философия как гениальный экспериментатор отбирает людей, готовых посвятить свою жизнь заложенному в них предопределению творчества в самом широком смысле, как творчеству культуры (они стали создателями философии как отрасли культуры), как жизнетворчеству (желание изменить социальный и политический строй общества) и как самотворчеству. Ключевые слова: самотворчество; Античность; духовное упражнение; созерцательность; самоконтроль; Платон; платонизм; Аристотель; аристотелизм; кинизм; эпикурейство; стоицизм

\section{BВЕАЕНИЕ}

$\bigwedge$ анная работа является завершением цикла работ авторов по проблеме формирования системы духовных упражнений как основы самотворчества (СТ) в Античности (Горелов, Горелова, 2019аb, 2020). Аля определения философского статуса понятия «самотворчество» было проведено его сравнение с близкими по смыслу понятиями: «творчество», «самосовершенствование», «творчество жизни», «самоактуализация», «практика себя» и «культура себя» (Горелов, Горелова, 2019а: Электронный ресурс). Самотворчество, как и творчество в целом, можно отнести к высшей способности человека - духовности. Поскольку именно дух «ответственен» и за появление идеи «надмирного, бесконечного и абсолютного бътия» (Шелер, 1988: 89), и за ее осуществление, постольку человек пытался создать практики его «тренировки». Зачатки духовных практик обнаруживаются уже в античной культуре: нарождающаяся отрасль духовной культуры - философия - содержит в себе элементы методологии воздействия на человека, которые можно назвать «духовными упражнениями». Первую систематическую методологию изменения поведения человека предложила знаменитая в Античности школа Пифагора, создавшая особую систему воспитания, которая способствовала самораскрытию человека. Учение Пифагора закладывает общие основания концепции самотворчества, согласно которой самотворчество связано с творчеством; требует волевого решения избранных творческих задач; становится способом духовной самоидентификации (Горелов, Горелова, 2019b).

Развитие аналогичных методологий во всех последующих школах Античности свидетельствует о том, что эти упражнения плодотворны и способствуют как изменению 
видения мира, так и метаморфозу личности, поскольку воздействие затрагивает не только интеллект, но и всю психику и поведение индивида, возвышая и обращая его «к жизни объективного Ауха» (Адо, 2005: 22). Типология духовных упражнений, предложенная французским философом П. Адо, выделяет универсальный не только для Античности, но и для всей последующей истории СТ базис: значение духовных упражнений для жизни - «научиться жить»; для контроля за чувством страха - «научиться умирать»; для социальной жизни - «научиться вести диалог» и «научиться чтению». Об универсальности античных упражнений свидетельствует аналогия с принципами «глубинного общения» (Г. С. Батищев), сформулированными значительно позже, в эпоху, когда этого общения стало явно недоставать, в XX в. Аналогия обнаруживает, что установка «научиться жить» соответствует принципам мироутверждения и со-причастности у Батищева; установка «научиться диалогу» предполагает предваряющее уважение к другим (уважение к человеку как субъекту, прощение); установка «научиться чтению» - «глубинное чтение» на основе позиции принципиального «несвоецентризма», не-антропоцентризма; установка «научиться умирать» восстанавливает приоритет безусловно-ценностного отношения к миру приоритет абсолютного над относительным, высшего над низшим, более совершенного над менее совершенным (Батищев, 2015: 534-538).

Внутренним каркасом всех упражнений является присутствие двух уровней: 1) paционального созерцания, которое в одних упражнениях проявляется открыто («научение жизни», «научение смерти»), а в других - скрыто ( «научение диалогу и чтению»), и 2) самоконтроля, «врачевания души», что способствовало смене видения и бытия человека (Горелов, Горелова, 2020).

В данной работе мы проследим позиции различных философских систем (школ) Античности в отношении возможности самоизменения человека, имея в виду три из четырех названных выше типов духовных упражнений: «научиться вести диалог»; «научиться чтению»; «научиться умирать» (принципы «научения жизни», как уже отмечалось, изложены в предыдущей работе, см: там же).

\section{АУХОВНЫЕ УПРАЖНЕНИЯ}

\section{КАК УНИВЕРСААЬНАЯ ОСНОВА САМОТВОРЧЕСТВА}

Ауховные упражнения «научиться вести диалог» и "научиться чтению» мы объединяем в одну группу - «научиться общению с Аругим», имея в виду, что диалог - это непосредственное общение, а чтение - это опосредованное общение через текст с той же целью - найти истину. Но, следуя диалектике сходства и отличия, нужно отметить, что различие между этими двумя группами духовных упражнений, на которое обращает внимание П. Адо, оправдано, так как глубинное общение - это общение с ныне живущим социумом, а глубинное (или, как еще его называют, медленное) чтение - это общение с вневременной культурой и мудростью.

Ауховные практики общения как диалога начинаются с Сократа, который впервые ставит вопрос о способах достижения истины. Современники отмечали силу воздействия его речей на окружающих. Алкивиад в «Пире» говорит: «Когда я слушаю его, сердце у меня бьется гораздо сильнее, чем у беснующихся корибантов (корибанты жрецы фригийской богини Кибелы. - A. Г., Т. Г.), а из глаз моих от его речей льются слезы; то же самое, как я вижу, происходит и со многими другими» (Платон, 1993b: 126 (Пир. 215е)). Античный диалог не является возможностью обучения и передачи знаний (как мы считаем сейчас): он ощущается как совместное усилие равноправных 
заинтересованных индивидов в поиске истины, причем радость ее переживания также является общей. Практика сознательного умственного сосредоточения в диалоге с другим человеком затем может быть перенесена на внутренний диалог. «Только тот, кто по-настоящему способен на встречу с другим, способен на подлинную встречу с самим собой, и наоборот» (Адо, 2005: 37). Методологически диалог усилиями вопрошающего и отвечающего прочерчивает маршрут мысли к истине. В этом случае необходимо искусство соразмерности, когда задающий вопросы понимает состояние и уровень подготовки отвечающего на них. Истина важна, но гораздо важнее прийти к ней сообща, совместными усилиями.

Аиалектический диалог, практикуемый Платоном, представляет самую высокую возможность разговора, потому что в скрытом виде в нем присутствует и азарт конкурентной борьбы (которая вообще присуща мужскому поведению), и радость консенсуса, возникающая в момент «Эврика!». Таким образом, в диалоге скрыто присутствует реальное желание обоих собеседников найти истину и обоюдная вера в такую возможность. Сократ говорит: «И, веря в истинность этой речи, я хочу вместе с тобой поискать, что же такое добродетель» (цит. по: Платон, 1990b: 589 (Менон, 81e)). Глубинный уровень диалога определяется процессом формирования идеи: «Идея... это не субъективное индивидуально-психологическое образование "с постоянным местопребыванием" в голове человека; нет, идея интериндивидуальна и интерсубъективна, сфера ее бытия не индивидуальное сознание, а диалогическое общение между сознаниями. Идея - это живое событие» (Бахтин, 1972: 146-147). Живая событийность создает особый климат творчества - «дух полифонического сотрудничества» (Батищев, 2015: 538). В идеале речь скорее может идти об исполнении каждым собственной партии в «оркестре» человечества, готовом к симфоническому звучанию.

Что касается общения через текст («научение чтению»), то Адо достаточно убедительно показывает, что философские системы Античности - это в основном своды комментариев философов-учителей для их учеников, устремленных встать на новый путь. Поскольку философия заключается не в преподавании конкретной теории, а в установке на особый стиль жизни, то она как любовь к мудрости должна помогать торить дорогу каждому конкретному собеседнику, живущему в определенную эпоху. Античные мудрецы понимали, что идеал полного освобождения от страстей и познания абсолютной истины в принципе не достижим, только философия как непрерывное поступательное движение к истине, синтезируя разные субъективные точки зрения, способна приблизить человека к идеалу. Понимание смысла доктрин и комментариев различных авторов, умение выбрать из них практики, соответствующие собственным внутренним возможностям, и есть правильная способность «читать». Античное чтение - это умение формировать на основе чужих теоретических построений собственный новый образ жизни, т. е. практическое умение обретается через духовное усилие. Глубинный поток «научения чтению» означает возможность встречи людей через расстояния и эпохи - автора и читателя, учителя и ученика, «свободный дар встречи, дар междусубъектности» (Батищев, 2015: 538). Такая встреча «гармонично происходит тогда, когда субъект становится достойным расширения и углубления его креативности за прежние пределы» (там же), т. е. как результат СТ.

Последняя группа духовных упражнений «научиться умирать» предлагает при выборе между Жизнью и Идеей (Благом) выбрать последнее, как это сделал Сократ, обосновав навеки фундаментальность такого философского выбора. Проблема пренебрежения смертью была поставлена еще Пифагором, но, будучи мистиком, он был 
уверен в бессмертии нематериальной души, которая многократно могла воплощаться на земле, совершая постепенное восхождение. В последующих философских системах «научение смерти» понималось как подчинение телесного желания жить высшим требованиям сознания и духа. Освобождение от тела как от оков в философском смысле не имеет ничего общего с мистическими состояниями транса, нирваны и т. А. Это сознательная процедура освобождения от страстей ради обретения независимости мышления, его перехода к универсальности и объективности. Созерцательная деятельность по изучению природы становится оправданной ради особого состояния мысли. Самостоятельным духовным упражнением для укрепления души становится любое познание, в том числе и наука (в Античности физика), которая понимает мир как храм, а человека как существо, способное подняться до уровня всеобщности и универсальности, т. е. до божественного созерцания.

Именно эту сторону «научения смерти» имеет в виду и концепция глубинного общения, которая предполагает, что мироутверждение - это не компромиссная готовность «учесть» бытие мира вне нас и независимо от нас - по логике хитрости, но бесхитростное, безусловное предпочтение Универсума - себе, своему сознанию и бытию (там же: 534). Смерть отступает для того, кто ценностям типа «после нас хоть потоп» противопоставляет ценность быть «субстанциональным деятелем» (Н. О. Аосский), т. е. творческим участником общей духовной эволюции человечества.

Изначальный мотив философа, который, собственно, и является творчеством, создать свое рачиональное представление о состоянии совершенства и соответствующие духовные практики, упражнения разума, настраивающие индивидуальную жизнь на духовное продвижение к идеалу мудрости, к божественному проявлению в себе как субъекте некоего Всеобщего. Ауховные практики, которые при этом создавались, были СТ их авторов, но поскольку у каждого из них находилось много последователей, эти упражнения несли в себе ядро всеобщего, как бы общий план структуры и возможностей СТ в рамках философии. Рассмотренные здесь типы духовных упражнений были ядром философских систем Античности начиная от Сократа, Платона, Аристотеля и их последователей, а позже систем Эпикура, киников, стоиков и неоплатоников. Вклад каждого из философских направлений в реализацию определенного типа духовных упражнений и в СТ различен и определяется центральной идеей концепции.

\section{«НАУЧИТЬСЯ ОБЩЕНИЮ С АРУГИМ »}

\section{КАК УНИВЕРСАИЬНАЯ ВЗАИМНАЯ СОПРИЧАСТНОСТЬ}

Основателем этой группы духовных упражнений следует также признать Сократа. Он первым осознал значение диалога не как способа обучения и преподавания: собеседник Сократа нового знания не приобретал, но пробуждался к познанию прежде всего самого себя. Как неутомимый «овод» (Платон, 1990а: 85 (Апология Сократа. 30e)), Сократ «жалит» своих собеседников вопросами, которых те себе никогда не задавали, принуждая их задуматься о своей жизни. Как и в случае жесткого тестирования в школе Пифагора, Сократ одних пробуждал своими вопросами, другие о них скоро забывали, но третьи, среди которых были люди взрослые, известные и богатые, бесцеремонно разоблаченные нищим философом, затаивали злобу, которая в конце концов и привела к «демократическому» голосованию за насильственную смерть Сократа.

Но для тех, кто мог слышать, «сократический диалог представляется... как практикуемое совместно духовное упражнение, которое призывает... к вниманию к себе, 
к знаменитому “познай самого себя” (Адо, 2005: 36). Практикуемый Сократом метод диалога - майевтика - так же способствует рождению мысли об истине, как повитуха помогает рождению реального ребенка. Как и жизнь ребенка, жизнь собеседника Сократа как бы рассечена надвое - до начала диалога и после него: в результате ошеломляющего открытия себя человек уже не может быть таким, каким был раньше, тем, кто полон спешки и бежит от себя самого. Сократовский диалог возможен лишь в условиях особого, духовного равенства, задающего вопросы и отвечающего на них: внимание ученика - это возможность для учителя познать самого себя, наличие учителя - это возможность для ученика понять самого себя. Сократ был первым, кто учил пробуждаться для СТ и передавать эту способность другому в цепи социальных контактов.

Киники изобрели свой способ разговора с согражданами - острый эпатажный уличный спектакль без различения социального статуса тех, к кому он был обращен. Известен анекдот, когда на предложение великого полководца Александра Македонского: «Проси у меня, чего хочешь» - Аиоген ответил: «Не заслоняй мне солнца» (Аиоген, 1986: 226). Высказываниями типа «грамматики изучают бедствия Одиссея и не ведают своих собственных; музыканты ладят струны на лире и не могут сладить с собственным нравом; математики следят за солнцем и луной, но не видят того, что у них под ногами; риторы учат правильно говорить и не учат правильно поступать; наконец, скряги ругают деньги, а сами любят их больше всего» (там же: 222-223) он задевал всех и каждого, одних - пробуждая к духовной жизни, других - толкая к ненависти. И в том, и в другом случае он прикасался к человеческим глубинам, просто эти глубины были наполнены разным содержанием.

Следующим шагом от диалога с Аругим является переход к диалогу с самим собой, на что указывал киник Антисфен. На вопрос, что дала ему философия, он ответил: «Умение беседовать с самими собой» (там же: 216). Поскольку сократический диалог предполагает присутствие наставника, то и диалог с самим собой осуществляется как бы в присутствии некого высшего Я (daimon, у Сократа), которое задает вопросы другому, маленькому, «я». Вероятно, главной опорой внутреннего диалога является способность к умственному сосредоточению, которое демонстрировал Сократ (например, во время военного похода на Потидею «как-то утром он о чем-то задумался... застыл на месте... простоял там до рассвета» (т. е. сутки. - А. Г., Т. Г.)) (Платон, 1993b: 131 (Пир, 220с - d)). Способностью независимо от обстоятельств предаваться своим мыслям, т. е. вести внутренний диалог, должен обладать каждый, кто хочет «дружить с мудростью», точно так же, как тот, кто посвящает жизнь СТ.

Платон в дополнение к физическому и этическому роду рассуждений, которые знал Сократ, ввел третий - диалектический. Правда, диалектика скорее относится к методу, а этика и физика - к содержанию рассуждений. В одном из диалогов Платона диалектиком называется тот, кто умеет особым образом ставить вопросы и давать ответы: «Чрезмерно разум напрягать не должен ты / Направь свободно мысль свою по воздуху, / Как стрекозу, привязанную за ногу» (Аристофан, 2000: 763).

Платоновский диалог имеет другой оттенок по сравнению с сократическим: «это сражение - дружеское, но реальное» (Адо, 2005: 38). Во взаимодействии двух собеседников присутствует в скрытом виде диалектическое усилие, которое предполагает, с одной стороны, совместное восхождение к истине, с другой - совместное усилие чистой мысли, с помощью Аогоса отворачивающее душу от земного чувственного существования к более высокому, божественному. Поскольку внутренний диалог также 
должен привести к изменению точки зрения или поведения, то он становится сражением с самим собой. Причем, как и в дружеском диалоге, «тема диалога менее значима, чем применяемый к ней метод, решение проблемы менее ценно, чем дорога, пройденная... чтобы ее решить» (там же: 39).

К устному диалогу добавляются письменные упражнения как усиление диалога с самим собой: по отношению к собственному письменному тексту читающий его становится посторонним наблюдателем, рефлектирующим о содержании прочитанного. Позже в христианстве письменный диалог становится исповедью, как, например, у Августина Блаженного. По существу, любая философская система Античности несет в себе диалог, открытый, как у Сократа и Платона, или скрытый, как у стоиков и Плотина, диалог, ведущийся пишущим с невидимым собеседником, который должен почувствовать ядро духовных упражнений и захотеть приобщиться к ним, чтобы полностью изменить свою жизнь и поведение. В таком случае именно диалог можно рассматривать как базовую методологию СТ, поскольку человек поворачивается к своему внутреннему миру, начинает его анализировать и переживать, учится понимать себя и т. п. Аиалог - начальный этап, азбука самоизменения. В нем также постигается радость момента откровения и состояния быстрого понимания. В диалоге СТ предстает как скрытое, незаметное, но упорное движение к цели, как продвижение к горизонту, который виден, но никогда не будет достигнут. Процесс СТ интригующе многомерен и в каком-то смысле важнее результата.

Существует еще одна форма выражения мыслей, более привычная для современного человека, - риторическая, которая предполагает постановку проблемы в виде вопроса и последующую дискуссию по нему. Конкретность поставленной проблемы держит мысль в определенных рамках, не позволяя расползаться и выдерживая направление. В Античности мы видим почти полную эволюцию риторического движения мысли: от тезисов и диатрибы (дискуссия по конкретному вопросу, поставленному в начале текста) через экзегезу (обсуждение не конкретного тезиса, а проблемы как таковой) к систематическим трактатам, которые выстраивались в гигантские схоластические здания (например, в неоплатонизме). Аля современного человека, как и для древнего грека, потребность в СТ может вырасти из необычно поставленного вопроса, прочитанной книги, разговора с человеком, «задевающего за живое».

Исходным пунктом для опосредованных через текст духовных упражнений («научиться чтению») также можно считать Сократа. У него не было учителей, оказавших большое влияние на мировоззрение и духовную практику, но Сократ был человеком определенного времени и определенной культуры, которые, конечно же, участвовали в его формировании. Его «школой чтения» можно считать постоянное самотестирование и творчество судьбы. Получилось так, что собственная его жизнь стала «книгой» для чтения, записанной теми, на кого она произвела неизгладимое впечатление, позитивное (Платон, Ксенофонт) или негативное (Аристофан).

В философских школах после Сократа знания, которые можно понимать как теоретические, становятся либо непосредственной основой духовной практики самоконтроля (у эпикурейцев и стоиков), либо практикой рациональной созерцательности (платоники, перипатетики). В соответствии с экзистенциальной целью философские тексты Античности имеют много отличий от современного теоретического знания. Во-первых, письменный трактат почти всегда написан в форме разговора с реальным (или мысленным) собеседником. Так записаны не только диалоги Платона, беседы Эпикура, но и учебные тетради Аристотеля, трактаты и комментарии стоиков. 
Они являлись отправной точкой для последующих свободных дискуссий на заданную тему.

Философский текст Античности не образует систематического знания как доктрины, скорее несет педагогические, психологические и методологические установки, уроки учителя для учеников. Этот метод, общий для всей Античности, можно назвать диалектическим, т. е. стремлением дать конкретный ответ на конкретный вопрос.

Главная цель «научения чтению» - донести общую установку для вовлечения в практику людей разного уровня - начинающих, продолжающих и чего-то достигших.

Текст должен соответствовать усилию по преобразованию человека, т. е. быть методологией формирования нового образа жизни. По аналогии с «глубинным общением» его можно назвать «глубинным чтением». Античные тексты «говорили» со своими читателями - современниками или теми, кто будет жить через тысячи лет.

Практическая философия должна быть одновременно и универсальной, чтобы выразить объективные цели, к которым следует стремиться, и конкретной, чтобы помочь отдельному человеку избрать свое направление самоизменения. Это одно из измерений античного философствования. Аругое измерение рождается в результате того, что жаждущий новой жизни философ является в то же время обычным человеком, и его разрывает между сферой повседневного и сферой прояснения разума, между тем, что в XX в. М. Хайдеггер назвал неподлинным и подлинным существованием. «Научиться читать» - значит совершить жизненный переворот, радикально изменить свое отношение к миру, оторваться от привычек и предрассудков своего времени. Третьим измерением античного «чтения» является тот факт, что каждый философ создает свой ракурс изучения проблемы или подхода к внутреннему миру человека. Задавая определенные вопросы под новым углом зрения, принимая разные отправные точки, античная философия фактически на всем своем протяжении использует dialegoтai - диалектический метод ведения диалога, изобретенный Платоном.

Аиалектическое «чтение» Античности, склонное к вглядыванию в глубины Универсума и внутреннего мира человека, сильно отличается от современного «поглощения» информации, которая плохо усваивается и затрагивает только «вершки» сознания. Современные тексты почти не ведут диалога с нами, они развлекают, заполняют время, слегка образовывают, но больше не составляют духовного упражнения. Сетевая жизнь с гаджетами в руках и в социальном смысле «разлучает с Аругим», потому что больше невозможно общение «глаза в глаза», которое только и дает глубинное познание человека. Появился термин, точно отражающий содержание этой новой болезни века, - числовой аутизм (digital autism). К деконструкции человека в телесном смысле (операции по изменению лица и тела или более кардинальные - смена пола) добавляется социальный аутизм, замкнутость на себя, что не способствует СТ, а становится уничтожением личности.

Таким образом, и «научение вести диалог», и «научение чтению» подразумевают открытое, свободное, устремленное на поиск истины общение с Аругим, которое можно назвать «глубинной дружбой». Аобавление слова «глубинный» Античности не требовалось: philia предполагала духовную близость и сходство уровня интеллекта. Не только для творчества, но и для СТ «...необходимо не просто “столкновение” или соприкосновение безразличных друг для друга творчеств, каждое из которых вполне могло бы совершаться и без такого соприкосновения, необходима внутренняя их сопричастность и сущностная взаимность, их бытие ради друг друга, их посвященность и адресованность друг другу, их истинно гармоническое взаимоотношение» (Батищев, 
1997: 114). Античные философы осознавали, что встреча двух миров - микрокосма и макрокосма - возможна лишь в том случае, если неисчерпаемой и бесконечной глубине Универсума соответствует креативная глубина бесконечно становящегося бытия человека (там же: 152-153). Многовековое существование большинства античных школ свидетельствует о том, что они создали плодотворные системы воспитания как общения учителя с учеником и самовоспитания через глубинное общение с Аругим.

\section{«НАУЧЕНИЕ СМЕРТИ» КАК МИРОУТВЕРЖАЕНИЕ}

Последняя группа духовных упражнений - «научиться умирать» - предполагает не только возможность, но и необходимость выбора между индивидуальной телесной жизнью и универсальной рациональностью (Иогосом). Этот выбор опять-таки первым совершает Сократ, который «умер из верности Аогосу» (Адо, 2005: 41). Сократ не противится нелепому оговору и предвзятости афинского суда, а как бы даже способствует его исполнению, не защищая себя и утверждая в приписываемой ему как сочиненной накануне смерти басне: «Кто добродетелен, тот выше людского суда» (Аиоген, 1986: 106). Раскаяние афинян наступило очень скоро. «...Сгубили, сгубили вы / Соловья Аонид, премудрого, непреступного...» - укоряет их Еврипид (там же). Среди причин насильственной смерти Сократа главной является та, от чего предостерегал сам великий мудрец, - человеческие страсти - зависть, ненависть, тщеславие и т. п., но они не навредили, а скорее завершили целостность СТ его жизни.

Следуя логике Сократа, киник Аиоген выбирает смерть как предел предпочтения и почитания. На вопрос, каких людей считает благородными, он отвечал: «Презирающих богатство, славу, удовольствия, жизнь, но почитающих все противоположное бедность, безвестность, труд, смерть» (Фрагменты ..., 1989: 140). Босой, полуодетый, не имеющий ни жилища, ни постоянного источника пищи, «гражданин мира» как бы перешагивает черту страха смерти и становится «гражданином Вселенной», утверждая приоритетность Универсума над своей и любой другой субъектностью. Через приобщение смерти киник как бы вмещает и олицетворяет на практике «глубинное бытие».

Платоновская формула философии как упражнения в «научении смерти» оказала огромное влияние не только на античную мысль, но и вообще на всю европейскую философию. Если на стадии «учиться жить» человек пытается «докопаться» до своей индивидуальности, то «...упражняться в науке смерти - это упражняться в умерщвлении своей индивидуальности, своих страстей для усмотрения вещей в перспективе универсальности и объективности» (Адо, 2005: 42). Ауховные «упражнения смерти» удивительным образом сходятся и переплетаются в рассматриваемых философских школах, и их можно разделить на три уровня. Первый уровень назовем упражнениями по подчинению желания жизни тела высшим требованиям мысли. По Платону, способности «учиться умирать» сопутствует прием, который можно назвать духовным разделением души и тела: душа приучается "собираться из всех его (тела. А. Г., Т. Г.) частей, сосредотачиваться самой по себе и жить... наедине с собой, освободившись от тела как от оков» (Платон, 1993а: 19 (Федон. 67d)). Поскольку цель души - вернуться в мир идей, то, чем раньше она освободится, тем скорее завершится ее земной цикл.

Аристотель в соответствии со своей общей идеей единства материи и формы рассматривает душу как сущность (форму) и осуществление (энтелехию) тела: «...Ауша необходимо есть сущность в смысле формы естественного тела, обладающего в воз- 
можности жизнью. Сущность же [как форма] есть энтелехия» (Аристотель, 1976: 394 (О душе. 412 a10)). Иными словами, душа не может быть отделена от тела, поэтому ни в одном из своих трактатов он не указывает на возможность продолжения существования индивидуальной души после смерти тела. Но в то же время, рассматривая бессмертие богов, он называет последнее видовым отличием для некоторых живых существ как иное «обстоятельство» или «состояние» жизни (Аристотель, 1978: 425 (Топика. 126 b35)). Он подчеркивает неоднозначность трактовки понятия «бессмертие», которое оказывается связанным с логикой времени, действия и субъекта. Скорее Аристотелю можно приписать идею безличностного бессмертия божественного духа (Неба), но фактических указаний на возможность для души человека достичь этого состояния у него нет. Как истинный ученый, он не пытается решить проблему, не имеющую эмпирического опыта.

Материалист-атомист Эпикур, хотя и ставит проблему разделения, но решает ее иначе. Ауша телесна и ведет себя в процессе умирания точно так же, как тело. «...Ауша есть тело из тонких частиц, рассеянное по всему нашему составу... оно схоже с ветром, к которому примешана теплота. Именно душа является главной причиной ощущений. $<\ldots .>$ Наконец, когда разрушается весь наш состав, то душа рассеивается и не имеет более ни прежних сил, ни движений, а равным образом и ощущений. <...> Поэтому те, кто утверждает, что душа бестелесна, говорят вздор: будь она такова, она не могла бы ни действовать, ни испытывать действие» (цит. по: Аиоген, 1986: 386). Ауша как особое сочетание атомов дана каждому конкретному человеку, чтобы совершить свой выбор и путь в данной единожды жизни.

Стоики, отталкиваясь, как и Платон, от бестелесности и бессмертия души, трактуют тело как презренную плоть, которой не стоит дорожить: «...кровь да кости, бренное плетение из нервов, жил, артерий» (Марк Аврелий, 1995: 277 (II, 2)). Аа и сама проблема разделения души и тела не имеет большого значение, поскольку смерть это «или рассеяние, если все атомистично, или угашение и изменение, если все едино» (там же: 317 (VII, 32)). Эпиктет вводит понятие чужого, относя к нему и тело. Правильные мнения, по Эпиктету, заключаются «в том, чтобы человек, целыми днями приучая себя к этому, не испытывал привязанности ни к чему чужому, ни к другу, ни к месту, ни к гимнасиям и даже к своему телу, а памятовал о законе и имел его перед глазами» (Беседы Эпиктета, 1997: 124). «А что это за закон? - вопрошает он. - Закон бога. Свое сохранять, на чужое не притязать, пользоваться тем, что дается, не жаждать того, что не дается, а когда отнимается что-то, отдавать легко и тут же, с благодарностью за все время пользования этим» (там же). Не испытывай привязанности к чужому - и ты не будешь желать этого и переживать из-за потери этого. «Очисть мнения: не пристало ли к тебе что-нибудь не-твое, не приросло ли, не причинит ли тебе мучений, если будет отрываться от тебя?» (там же: 226). Этими духовными упражнениями нужно заниматься каждый день, как тренируют свое тело гимнасты. Все философские направления сходятся в едином выводе: тело - это пробный шар, которым нужно овладеть, чтобы душа могла очиститься и выполнить свою миссию.

Второй уровень «упражнений смерти» назовем «живи здесь и сейчас». По Платону философия дает возможность человеку отстраниться от страха смерти, потому что ему «предназначено вечно стремиться к божественному и человеческому в их целокупности» (Платон, 1994: 264 (Государство. 486а)). Перед лицом созерцаемой вечности не может быть страха за собственную жизнь. По Аристотелю философия настолько внутренне преобразует человека, что фактически возникает новая форма жизни - 
жить согласно уму. И ум, достигший определенного уровня развития - мудрости, не умирает, а переходит в вечность. Аля Эпикура осознание конечности существования человеком, вглядывающимся в глубины Вселенной, ведет не к страху, но придает цену каждому мгновению жизни: «Аумай про каждый день, / Что сияет тебе он последним; / Радостью снидет тот час, которого чаять не будешь» (Аиоген, 1986: 402). Воспоминание о прошлом имеет смысл, если приносит удовольствие и радость: «...заниматься философией следует и молодому, и старому: первому - для того, чтобы он и в старости остался молод благами в доброй памяти о прошлом, второму - чтобы он был и молод, и стар, не испытывая страха перед будущим», - уверен Эпикур (там же: 402). Удовольствие заключено в духовном упражнении созерцания Вселенной, а повседневность очень проста: «Голос плоти - не голодать, не жаждать, не зябнуть. У кого есть это и кто надеется иметь это в будущем, тот даже с Зевсом может поспорить о счастье» (Эпикур, цит. по: Адо, 2005: 31). Стоики пошли дальше в осознании настоящего и, можно сказать, создали «философию мгновения»: человеческие страсти рождаются либо от переживаний прошлого, либо от неизвестности будущего и не зависят от нас. Мы властны лишь над нынешним мгновением, только им можно овладеть: «Не выходи за пределы настоящего», - призывает Марк Аврелий (Марк Аврелий, 1995: 317 (VII, 29)). Это означает: освободить себя от треволнений и повседневных забот и ежеминутно практиковать духовные упражнения по согласованию своей воли с космическим сознанием, вписываясь в его универсальные законы. «Всюду и везде в твоей власти и довольствоваться благочестиво своим наличным жребием, и относиться справедливо к находящимся налицо людям, и исследовать внимательно наличные представления, дабы не проникло в них ничего несообразного» (там же: 320 (VII, 54)).

Третий уровень «упражнений смерти» предполагает работу по «возвышению души». Платон считал, что приобщившийся к бессмертию мысли не может страшиться смерти тела. «Научившийся смерти» просто-напросто меняет перспективу собственной жизни и на смену виденью через страсти и страхи приходят «возвышенные помыслы и охват мысленным взором целокупного времени и бытия» (Платон, 1994: 264 (Государство. 486а)). В перспективе чистого духовного образа человеческая повседневность предстает малозначимой. В духовном смысле «упражнение смерти», по Платону, есть возвышение мысли, переходящей от субъективной повседневности к универсальной объективности мира идей. Так душа исцеляется от страха смерти, что было оценено его современниками в эпитафии Платону: «Авух Аполлон сыновей Эскулапа родил и Платона: / Тот исцеляет тела, этот - целитель души» (Олимпиодор, 1986: 415). По Аристотелю, душу возвышает духовное наслаждение, обретаемое в процессе познания: «Природа отдает тому, кто изучает ее плоды, чудесные наслаждения, лишь бы мы были способны восходить до причин, и действительно были бы философами» (Аристотель, цит. по: Адо, 2005: 47). Универсальный мотив философской практики Эпикура - тетрафармакон («четверолекарствие») был высечен спустя два столетия после его смерти на мраморной стеле: «Нечего бояться богов, / Нечего бояться смерти. / Можно переносить страдания. / Можно достичь счастья» (Аиоген, 1986: 373). У стоиков находим образ парящей души: «...поправ всякое зло и устремляясь ввысь, душа проникает в сокровенную глубину природы и в әтом обретает самое полное и совершенное благо, какое только может выпасть на долю человека. <...> пока она не обойдет весь мир... и не скажет себе: “И что - это та самая точечка, которую столько племен делят между собой огнем и мечом?” О как смешны все эти границы, устанавливаемые смертными» ([Сенека] Ауций Анней Сенека, 2001: 182-183). 
Аля стоиков «научение смерти» становится дорогой к свободе. Эпиктет подчеркивает значение размышлений о смерти для изменения внутреннего мира: «Смерть и изгнание и все, что вызывает страх, пусть будет у тебя ежедневно перед глазами, в особенности смерть - ибо так ты никогда не станешь думать ни о чем низком и не пожелаешь ничего сверх меры» (Эпиктет, 2012: 64 (XXI)). У Сенеки мотив самоубийства как освобождения облекается в форму нормы: «Тому, кто попал в руки владыки, поражающего стрелами его друзей, тому, кого господин принуждает вырвать внутренности у родных детей, я скажу: что ты рыдаешь, безумец, чего ты ждешь? Чтобы враг уничтожил твой род, чтобы какой-нибудь чужой владыка напал на тебя? Куда бы ты ни обратил свой взор, всюду ты найдешь исход из своих бедствий! Взгляни на этот крутой обрыв - он ведет к свободе, взгляни на это море, этот поток, этот колодезь - на дне их таится свобода; взгляни на это дерево - невысокое, засохшее, жалкое - с него свешивается свобода. Твоя шея, твоя гортань, твое сердце - они помогут тебе избежать рабства. Но эти пути слишком трудны, они требуют большой мощи, душевной и телесной; ты спросишь, какой же еще путь к свободе открыт; он в любой кровеносной жиле твоего тела» (Сенека, 1962: 81). Смерть выступает у него и как критерий прожитой жизни: «Все наши прежние слова и дела - ничто... Смерть покажет, чего я достиг, ей я и поверю <..> Смерть не есть зло. - Ты спросишь, что она такое? Единственное, в чем весь род людской равноправен» (Сенека, 1977: 50, 320). Сенека не «взвешивает» удовольствие и страдание, как Эпикур, для него смерть - способ освобождения. Больше, чем любая другая философская система, стоицизм становится духовным упражнением «научения умирать».

Ауховная свобода делает людей равноправными в социуме. «Они рабы? Нет, люди. Они рабы? Нет, твои соседи по дому. Они рабы? Нет, твои смиренные друзья. Они рабы? Нет, твои товарищи по рабству, если ты вспомнишь, что и над тобой, и над ними одинакова власть фортуны» (там же: 77). Но это «товарищество» по рабству освобождает человека хотя бы потенциально: «Рабство не проникает в человека в целом - лучшая часть его изъята из рабства. Только тело его подневольно и принадлежит господину, но душа его принадлежит самой себе. $<$...> Тело является тем, что по воле судьбы отдано во власть господина, он его покупает и продает; внутренняя же сущность не может быть отдана в рабство» (там же). Правоту и объективность этой стоической установки на равноправие подтверждает история: из трех самых известных римских стоиков один (Сенека) был придворным, другой (Эпиктет) - рабом, а третий (Марк Аврелий) - императором.

Приученный не учитывать болезни тела и не бояться смерти, человек растворяет иллюзии индивидуальности и поднимается до видения всеобщности и возвышения сознания к пониманию универсальности. Рождается состояние приобщенности к Универсуму. «Пора не только согласовывать свое дыхание с окружающим воздухом, но и мысли со всеобъемлющим разумом. Ибо разумная сила так же разлита и распространена повсюду для того, кто способен вбирать ее в себя, как сила воздуха для способного к дыханию» (Марк Аврелий, 1995: 331 (VIII, 54)).

Позже неоплатоники систематизировали духовные упражнения в соответствии с этапами духовного роста: от очищения души посредством отделения от тела через познание и превосхождение чувственного мира к обращению к Единому, которое у них означает Бога. Человек должен уподобить свою жизнь работе ваятеля статуй, который «одно отсекает, другое шлифует»; так «и ты отсекай чрезмерное, выпрямляй искривленное, темное очищай и делай блестящим и не прекращай “ваять свою ста- 
тую”, пока не осияет тебя боговидная красота добродетели» (Плотин, 2004: 239 (I, 6, $9,7)$ ). В интерпретации Плотина нематериальная и бессмертная душа настолько обладает индивидуальностью, что человек, отделивший душу от всякой конкретной формы и отстранивший ее от всех вещей, «словно бы становится другим и больше не есть он сам и не принадлежит себе, но становится принадлежащим Ему и есть Единое, соприкасаясь с Ним как центр с центром» (Плотин, 2005: 316 (VI, 9, 10)).

Фактически описания всех духовных упражнений «научения смерти» имеют оттенок пережитого, в них сквозит сильное желание передать прочувствованное другим, идущим следом. Практическая философия в них проявляется как страстный призыв овладеть собственной жизнью, посвятить себя без остатка творческому эксперименту над самим собой, не отвлекаясь на обыденность. Ступивший на этот путь не только узна́ет себя, свою бессмертную душу, но и приобщится к вечности (Иогосу, или у неоплатоников - Единому как началу всех вещей). Она подводит к пониманию того, что делать, но не дает рецепта, как делать. Путь научения смерти - это СТ в наиболее сильной форме.

\section{ЗАКАЮЧЕНИЕ}

Философия Античности и в наше время не ощущается как устаревшая система представлений. Это не пройденный исторический этап жизни человечества, а скорее первоначальный заряд этой истории, который остается востребованным в силу того, что несет в себе энергию творчества, которая может стать толчком для движения духа в любые эпохи. Огромно ее значение как практической системы, которая, раскрыв одновременно всеобщее (Иогос) и индивидуальность (Иичность), показала, что путь к всеобщему лежит через индивидуальность и сам этот путь есть движение к глубинному себе через СТ. Античная философия не относила себя к системе творчества: она претендовала на поиск лежащей где-то истины, а не считала, что творит новое. В этом смысле античное СТ также является поиском, но поиском внутренним - истины внутри человека. Но время распорядилось по-своему и добавило к именам создателей античных философских систем определение «гениальный творец».

Практическая направленность античной философии вполне рационально толкала человека к самоизменению, более того, она создала методологию СТ: самоконтроль как способность минимизировать ненужное для творчества и созериание - как способность к расширению сознания, для него необходимого. Главной составляющей обоих уровней является устремленность: ничто не дается даром, ведь результат зависит от правильности выбора. Самоконтроль через систему духовных упражнений как бы защищает человека от бесполезного разбазаривания жизненной энергии, которая нужна не для самоутверждения, а для глубинного приобщения к Универсуму (мироутверждению, по Г. С. Батищеву). Античная философия предлагает разные способы такого «глубинного общения» с миром: это простота и парадоксальность у киников, отказ от чувственного и концентрация сознания - у платоников, логическая последовательность - у перипатетиков, отрешение от мира - у эпикурейцев, бодрствуюшее сознание и непротивление судьбе - у стоиков. Все это разнообразие целей и практик объединяет нечто общее - самоизменение в сторону улучшения, самоосуществление, несмотря на внешние условия. Каждая философская система это одновременно и точка перелома, и ориентир, подобно камню в русской сказке с надписью: «налево пойдешь... направо пойдешь...», который предупреждает о том, что ждет на этом пути. 
Философия как гениальный экспериментатор отбирает людей, готовых к эксперименту над собой, так сказать, посвященных в ее требования и обязующихся перед вечностью посвятить свою жизнь заложенному в них предопределению творчества в самом широком смысле - как творчеству культуры (они стали создателями философии как отрасли культуры), как жизнетвориеству (желание изменить социальный и политический строй общества) и как самотворчеству. Истинный философ живет в жестких рамках внутреннего устремления видеть универсальную природу вещей и отказа от условности обыденной жизни окружающих его людей. Он и посредник, и изгой-чужак, и он же осенен особым даром творчества и СТ.

Культуре Античности соответствует не образ сундука с сокровищами, прекрасные, но безжизненные артефакты которого интересно рассматривать, а, скорее, образ живой творческой системы, некоего Органона, взгляд на который с нового ракурса дает огромный материал для понимания себя, своей эпохи и культуры.

\section{СПИСОК АИТЕРАТУРЫ}

Адо, П. (2005) Ауховные упражнения и античная философия / пер. с фр. при участии В. А. Воробьева. М. ; СПб. : Степной ветер ; ИА «Коло». 448 с.

Аристотель (1976) О душе // Аристотель. Сочинения : в 4 т. / ред. В. Ф. Асмус. М. : Мысль. T. 1.520 c. C. $369-448$.

Аристотель (1978) Топика // Аристотель. Сочинения : в 4 т. / ред. 3. Н. Микеладзе. М. : Мысль. Т. 2. 687 с. С. 347-532.

Аристофан (2000) Облака // Аристофан. Комедии / пер. А. И. Пиотровского ; изд. подг. В. Н. Ярхо. М. : Наука-Аадомир. 1080 с. С. 146-226.

Батищев, Г. С. (1997) Введение в диалектику творчества. СПб. : РХГИ. 448 с.

Батищев, Г. С. (2015) Особенности культуры глубинного общения // Избранные произведения / под общ. ред. 3. К. Шаукеновой. Алматы : Институт философии, политологии и религиоведения КН МОН РК. 880 с. С. 505-538.

Бахтин, М. М. (1972) Проблемы поэтики Аостоевского. М. : Художественная литератуpa. $470 \mathrm{c}$.

Беседы Эпиктета (1997) / подг. Г. А. Таронян. М. : Аадомир. 412 с.

Горелов, А. А., Горелова, Т. А. (2019а) Самотворчество как протестный потенциал духовной культуры [Электронный ресурс]// Научные труды Московского гуманитарного университета. №1. C. 148-170. URL: http://journals.mosgu.ru/trudy/article/view/943 (дата обращения: 06.06.2019). DOI: $10.17805 /$ trudy.2019.1.14

Горелов, А. А., Горелова Т. А. (2019b) Осознание возможности самотворчества в Античности: школа Пифагора // Знание. Понимание. Умение. №3. С. 44-54. DOI: 10.17805/zpu. 2019.3.4

Горелов, А. А., Горелова Т. А. (2020) Роль самотворчества в становлении индивидуальности в Античности: духовное упражнение «научиться жить» // Знание. Понимание. Умение. № 1. C. 54-72. DOI: $10.17805 /$ zpu.2020.1.4

Аиоген, Ааэртский (1986) О жизни, учениях и изречениях знаменитых философов / ред. и авт. вступ. ст. А. Ф. Аосев, пер. М. А. Гаспарова. М. : Мысль. 571 с.

Марк Аврелий (1995) Наедине с собой. Размышления // Римские стоики: Сенека, Эпиктет, Марк Аврелий / вступ. ст., сост., подгот. текста В. В. Сапова. М. : Республика. 463 с. С. 271-363.

Олимпиодор (1986) Жизнь Платона // Аиоген Ааэртский. О жизни, учениях и изречениях знаменитых философов. Приложение / ред. и авт. вступ. ст. А. Ф. Аосев, пер. М. А. Гаспарова. М. : Мысль. 571 с. С. 412-415.

Платон (1990а) Апология Сократа // Платон. Собрание сочинений : в 4 т. / общ. реА. А. Ф. Аосева, В. Ф. Асмуса, А. А. Тахо-Годи ; примеч. А. Ф. Аосева и А. А. Тахо-Годи. М. : Мысль. Т. 1.860 с. С. 70-96. 
Платон (1990b) Менон // Платон. Собрание сочинений : в 4 т. / общ. ред. А. Ф. Аосева, В. Ф. Асмуса, А. А. Тахо-Годи ; примеч. А. Ф. Аосева и А. А. Тахо-Годи. М. : Мысль. Т. 1.860 с. C. $575-612$.

Платон (1993а) Федон // Платон. Собрание сочинений : в 4 т. / общ. ред. А. Ф. Мосева, В. Ф. Асмуса, А. А. Тахо-Годи; примеч. А. Ф. Аосева и А. А. Тахо-Годи. М. : Мысль. Т. 2.528 с. C. 7-80.

Платон (1993b) Пир // Платон. Собрание сочинений : в 4 т. / общ. ред. А. Ф. Аосева, В. Ф. Асмуса, А. А. Тахо-Годи; Примеч. А. Ф. Аосева и А. А. Тахо-Годи. М. : Мысль. Т. 2.528 с. C. 81-134.

Платон (1994) Государство // Платон. Собрание сочинений : в 4 т. / общ. ред. А. Ф. Аосева, В. Ф. Асмуса, А. А. Тахо-Годи; примеч. А. Ф. Аосева и А. А. Тахо-Годи. М. : Мысль. Т. 3.654 с. C. $79-420$.

Плотин (2004) Первая эннеада / пер., вступ. ст., коммент. Т. Г. Сидаша, Р. В. Светлова. СПб. : Издательство Олега Абышко. 320 с.

Плотин (2005) Шестая эннеада: Трактаты VI-IX // Плотин. Эннеады / пер. с древнегреч. и посл. Т. Г. Сидаша. СПб. : Издательство Олега Абышко. 416 с.

Сенека (1962) О гневе // История римской литературы : в 2 т. / под ред. С. И. Соболевского, М. Е. Грабарь-Пассек, Ф. А. Петровского. М. : Изд-во Академии наук СССР. Т. 2. 522 с. C. 326-390.

Сенека, А. А. (1977) Нравственные письма к Ауцилию. М. : Наука. 384 с.

[Сенека] Ауций Анней Сенека (2001) Философские трактаты. О природе / пер. с лат., вступ. ст., коммент. Т. Ю. Бородай. СПб. : Алетейя. 400 с.

Фрагменты ранних греческих философов (1989). Ч. 1. От эпических теокосмогоний до возникновения атомистики / подг. А. В. Аебедев. М. : Наука. 576 с.

Шелер, М. (1988) Положение человека в Космосе // Проблема человека в западной философии: Переводы / сост. и послеслов. П. С. Гуревича ; общ. ред. Ю. Н. Попова. М. : Прогресс. 552 c. C. $31-95$.

Эпиктет (2012) Энхиридион // Эпиктет. Энхиридион (Краткое руководство к нравственной жизни); Симпликий. Комментарий на «Энхиридион» Эпиктета / пер., коммент. Н. Я. Тыжов. СПб. : Владимир Ааль. 399 с. С. 55-83.

Аата поступления: 12.03.2020 2.

\section{THE ROLE OF SELF-CREATION IN THE FORMATION OF INDIVIDUALITY IN ANTIQUITY: SPIRITUAL EXERCISES "LEARNING TO COMMUNICATE WITH OTHERS" AND "LEARNING TO DIE" \\ A. A. GORELOV \\ RAS INSTITUTE OF PHILOSOPHY \\ T. A. GORELOVA \\ MOSCOW UNIVERSITY FOR THE HUMANITIES}

This paper is the end of a series of works on the issue of self-creation (SC) in antiquity. The authors trace the standpoints of various philosophical schools - Platonism, Aristotelianism, Cynicism, Epicureanism and Stoicism from the perspective of the four types of spiritual exercises proposed by P. Ado - "learning to live", "learning to conduct a dialogue", "learning to read" and "learning to die" (the previous paper is devoted to the exercise "learning to live").

The practical orientation of ancient philosophy quite rationally pushed man to self-change; it created the methodology of SC - self-control as the ability to not waste oneself in everyday life and contemplation as the ability to expand consciousness. The main component of both levels is aspiration. Philosophy as a genius experimenter selects people who are ready to devote their lives to the engrained predestination of creativity in the broadest sense - as the creativity of culture (they became the creators of philosophy as a branch of culture), as life creation (the desire to change the social and political structure of society) and as self-creation. 
Keywords: self-creation; antiquity; spiritual exercise; contemplation; self-control; Plato; Platonism; Aristotle; Aristotelianism; Cynicism; Epicureanism; Stoicism

\section{REFERENCES}

Ado, P. (2005) Dukbovnye uprazhneniia i anticbnaia filosofiia / transl. from Fr. Moscow, St. Petersburg, Stepnoi veter; ID «Kolo». 448 p. (In Russ.).

Aristotel' (1976) O dushe. In: Aristotel'. Sochineniia : in 4 vol. / ed. by V. F. Asmus. Moscow, Mysl'. Vol. 1. 520 p. Pp. 369-448. (In Russ.).

Aristotel' (1978) Topika. In: Aristotel'. Sochineniia: in 4 vol./ ed. by V. F. Asmus. Moscow, Mysl'. Vol. 2. 687 p. Pp. 347-532. (In Russ.).

Aristofan (2000) Oblaka. In: Aristofan. Komedii / transl. by A. I. Piotrovskii; ed. by V. N. Iarkho. Moscow, Nauka-Ladomir. 1080 p. Pp. 146-226. (In Russ.).

Batishchev, G. S. (1997) Vvedenie v dialektiku tvorchestva. St. Petersburg, RKhGI. 448 p. (In Russ.).

Batishchev, G. S. (2015) Osobennosti kul'tury glubinnogo obshcheniia. In: Izbrannye proizvedeniia / ed. by Z. K. Shaukenovaya. Almaty, Institut filosofii, politologii i religiovedeniia KN MON RK. 880 p. PP. 505-538. (In Russ.).

Bakhtin, M. M. (1972) Problemy poetiki Dostoevskogo. Moscow, Khudozhestvennaia literatura. 470 p. (In Russ.).

Besedy Epikteta (1997) / ed. by G. A. Taronian. Moscow, Ladomir. 412 p. (In Russ.).

Gorelov, A. A. and Gorelova, T. A. (2019a) Samotvorchestvo kak protestnyi potentsial dukhovnoi kul'tury. Nauchnye trudy Moskovskogo gumanitarnogo universiteta, no. 1, pp. 148-170 [online] Available at http://journals.mosgu.ru/trudy/article/view/943 (access date 06.06.2019). DOI: 10.17805/trudy.2019.1.14 (In Russ.).

Gorelov, A. A. and Gorelova T. A. (2019b) Osoznanie vozmozhnosti samotvorchestva v Antichnosti: shkola Pifagora. Znanie. Ponimanie. Umenie, no. 3, pp. 44-54. DOI: 10.17805/zpu.2019.3.4 (In Russ.).

Gorelov, A. A., Gorelova T. A. (2020) Rol' samotvorchestva v stanovlenii individual'nosti v Antichnosti: dukhovnoe uprazhnenie «nauchit'sia zhit'». Znanie. Ponimanie. Umenie, no. 1, pp. 54-72. DOI: $10.17805 /$ zpu.2020.1.4 (In Russ.).

Diogen, Laertskii (1986) O zhizni, ucheniiakh i izrecheniiakb znamenitykh filosofov / ed. by A. F. Losev, per. M. L. Gasparova. Moscow, Mysl'. 571 p. (In Russ.)

Mark Avrelii (1995) Naedine s soboi. Razmyshleniia. In: Rimskie stoiki: Seneka, Epiktet, Mark Avrelii / comp. by V. V. Sapov. Moscow, Respublika. 463 p. Pp. 271-363. (In Russ.).

Olimpiodor (1986) Zhizn' Platona. In: Diogen Laertskii. O zbizni, ucheniiakb i izrecheniiakb znamenitykh filosofov. Prilozhenie / ed. by A. F. Losev, transl. by M. L. Gasparov. Moscow, Mysl'. 571 p. Pp. 412-415. (In Russ.).

Platon (1990a) Apologiia Sokrata. In: Platon. Sobranie socbinenii : in 4 vol. / ed. by A. F. Losev, V. F. Asmus and A. A. Takho-Godi ; prim. A. F. Losev and A. A. Takho-Godi. Moscow, Mysl'. Vol. 1. 860 p. Pp. 70-96. (In Russ.).

Platon (1990b) Menon. In: Platon. Sobranie socbinenii : in 4 vol. / ed. by A. F. Losev, V. F. Asmus and A. A. Takho-Godi ; prim. A. F. Losev and A. A. Takho-Godi. Moscow, Mysl'. Vol. 1. 860 p. Pp. 575-612. (In Russ.).

Platon (1993a) Fedon. In: Platon. Sobranie sochinenii : in 4 vol. / ed. by A. F. Losev, V. F. Asmus and A. A. Takho-Godi ; prim. A. F. Losev and A. A. Takho-Godi. Moscow, Mysl'. Vol. 2. 528 p. Pp. 7-80. (In Russ.).

Platon (1993b) Pir. In: Platon. Sobranie socbinenii : in 4 vol./ ed. by A. F. Losev, V. F. Asmus and A. A. Takho-Godi ; prim. A. F. Losev and A. A. Takho-Godi. Moscow, Mysl'. Vol. 2.528 p. Pp. 81-134. (In Russ.).

Platon (1994) Gosudarstvo. In: Platon. Sobranie socbinenii : in 4 vol. / ed. by A. F. Losev, V. F. Asmus and A. A. Takho-Godi ; prim. A. F. Losev and A. A. Takho-Godi. Moscow, Mysl'. Vol. 3. 654 p. Pp. 79-420. (In Russ.). 
Plotin (2004) Pervaia enneada / transl. by T. G. Sidash and R. V. Svetlov. St. Petersburg, Izdatel'stvo Olega Abyshko. 320 p. (In Russ.).

Plotin (2005) Shestaia enneada: Traktaty VI-IX. In: Plotin. Enneady / transl. by T. G. Sidash. St. Petersburg, Izdatel'stvo Olega Abyshko. 416 p. (In Russ.).

Seneka (1962) O gneve. In: Istoriia rimskoi literatury : in 2 vol. / ed. by S. I. Sobolevskii, M. E. Grabar'-Passek and F. A. Petrovskogo. Moscow, Izd-vo Akademii nauk SSSR. Vol. 2. 522 p. Pp. 326-390. (In Russ.).

Seneka, L. A. (1977) Nravstvennye pis'ma k Lutsiliiu. Moscow, Nauka. 384 p. (In Russ.).

[Seneka] Lutsii Annei Seneka (2001) Filosofskie traktaty. O prirode / transl. by T. Yu. Borodai. St. Petersburg, Aleteiia. 400 p. (In Russ.).

Fragmenty rannikb grecheskikb filosofov (1989). Part 1. Ot epicheskikb teokosmogonii do vozniknoveniia atomistiki / prep. by A. V. Lebedev. Moscow, Nauka. 576 p. (In Russ.).

Sheler, M. (1988) Polozhenie cheloveka v Kosmose. In: Problema cheloveka v zapadnoi filosofii: Perevody / comp. by P. S. Gurevich; ed. by Yu. N. Popov. Moscow, Progress. 552 p. Pp. 31-95. (In Russ.).

Epiktet (2012) Enkhiridion. In: Epiktet. Enkbiridion (Kratkoe rukovodstvo $k$ nravstvennoi zhizni); Simplikii. Kommentarii na «Enkbiridion» Epikteta / transl. and comm. by N. Ia. Tyzhov. St. Petersburg, Vladimir Dal'. 399 p. Pp. 55-83. (In Russ.).

Submission date: 12.03 .2020 .

Горелов Анатолий Алексеевич - доктор философских наук, ведущий научный сотрудник Института философии РАН. Адрес: 119842, Россия, г. Москва, ул. Гончарная, д. 12. Тел.: +7 (495) 697-91-28. Эл. адрес: evolepis@iph.ras.ru

Горелова Татьяна Анатольевна - доктор философских наук, профессор кафедры философии, культурологии и политологии Московского гуманитарного университета. Адрес: 111395, Россия, г. Москва, ул. Юности, д. 5. Тел.: +7 (499) 374-55-11. Эл. адрес: fylosofy@mosgu.ru

Gorelov Anatoliy Alekseevich, Doctor of Philosophy, Leading Research Fellow, RAS Institute of Philosophy. Postal address: 12, Goncharnaya St., Moscow, Russian Federation, 119842. Tel.: +7 (495) 697-91-28. E-mail: evolepis@iph.ras.ru

Gorelova Tatyana Anatolyevna, Doctor of Philosophy, Professor, Department of Philosophy, Culturology and Politology, Moscow University for the Humanities. Postal address: 5, Yunosti St., Moscow, Russian Federation, 111395. Tel.: +7 (499) 374-55-11. E-mail: fylosofy@mosgu.ru 